\title{
1 Porites Calcifying Fluid pH on Seasonal to Diurnal Scales
}

2 Oliver Knebel ${ }^{1}$, Carlos Carvajal ${ }^{1}$, Christopher D. Standish ${ }^{2}$, Elwyn de la Vega ${ }^{2}$, Thomas B.

3 Chalk $^{2}$, Emma J. Ryan ${ }^{1}$, Weifu Guo ${ }^{3}$, Murray Ford ${ }^{1}$, Gavin L. Foster ${ }^{2}$, and Paul Kench ${ }^{4}$

$4 \quad{ }^{1}$ School of Environment, University of Auckland, Auckland, New Zealand. ${ }^{2}$ School of Ocean

5 and Earth Science, University of Southampton, Southampton, United Kingdom. ${ }^{3}$ Department of

6 Geology and Geophysics, Woods Hole Oceanographic Institution, Woods Hole, MA, USA.

$7 \quad{ }^{4}$ Department of Earth Sciences, Simon Fraser University, Burnaby, BC, Canada.

8 Corresponding author: Oliver Knebel (okne620@ aucklanduni.ac.nz)

\section{Key Points:}

- Porites calcifying fluid $\mathrm{pH}$ was investigated using conventional and laser ablation boron isotope analysis, and a calcification model

- On a seasonal scale, Porites calcifying fluid $\mathrm{pH}$ followed mainly seawater temperatures that control calcification rates

- On a diurnal scale, model estimates suggest limited calcifying fluid $\mathrm{pH}$ variability despite highly variable reef flat seawater conditions 


\section{Abstract}

Coral resilience to ocean acidification is largely determined by the degree of physiological control corals can exert on their calcifying fluid carbonate chemistry. In this study, the boron isotopic composition $\left(\delta^{11} \mathrm{~B}\right)$ of a Porites colony growing on a reef flat on Kiritimati Island in the equatorial central Pacific is examined to quantify the sensitivity of calcifying fluid $\mathrm{pH}\left(\mathrm{pH}_{\mathrm{cf}}\right)$ to ambient environmental conditions. Skeletal $\delta^{11} \mathrm{~B}$ along the growth axis of one annual growth band was determined with bulk analysis and by laser ablation (LA) MC-ICP-MS. Furthermore, the oxygen and carbon isotopic composition, trace element ratios, and skeletal density was quantified. Sclerochronological data were interpreted in the context of simultaneous recordings of reef flat seawater $\mathrm{pH}\left(\mathrm{pH}_{\mathrm{sw}}\right)$, temperature, salinity, and water depth, and by measurements of these parameters on the fore-reef. A recent model of $\mathrm{pH}_{\mathrm{cf}}$ upregulation, after optimization with seasonally resolved data, was used to simulate $\mathrm{pH}_{\mathrm{cf}}$ variability on a diurnal scale. Results showed that on a seasonal scale, Porites $\mathrm{pH}_{\mathrm{cf}}$ is upregulated compared to ambient seawater: both bulk and LA-MC-ICP-MS derived $\delta^{11} \mathrm{~B}$ resulted in a mean $\mathrm{pH}_{\mathrm{cf}}$ of $8.35 \mathrm{pH}$ units. Calcifying fluid $\mathrm{pH}$ upregulation primarily followed variations in seawater temperatures that is likely related to the control of temperature on calcification rate. On the reef flat, the diurnal range in $\mathrm{pH}_{\mathrm{sw}}$ was substantially higher ( $0.29 \mathrm{pH}$ units) than on the fore-reef ( $0.07 \mathrm{pH}$ units). However, model results suggest that the high diurnal variability in reef flat $\mathrm{pH}_{\mathrm{sw}}$ had only a limited effect on the variability in Porites $\mathrm{pH}_{\mathrm{cf}}$.

\section{Plain Language Summary}

Ocean acidification and the associated decline in seawater $\mathrm{pH}$ has impacted the ability of many marine organisms to calcify. However, tropical corals do not precipitate their aragonite skeletons from seawater, but instead from a calcifying fluid located between skeleton and living tissue. The chemistry of this calcifying fluid is modified by physiological processes. This study examines the sensitivity of the calcifying fluid $\mathrm{pH}$ to variations in environmental conditions. Seawater $\mathrm{pH}$, temperature, salinity, and water depth on a reef flat at Kiritimati Island in the central Pacific were monitored for one year. The calcifying fluid $\mathrm{pH}$ of a synchronously precipitated annual growth band of a Porites colony was determined using boron isotope analysis with dissolution of samples and novel laser ablation at enhanced resolution. Furthermore, a numerical model predicted calcifying fluid $\mathrm{pH}$ variability at a diurnal scale based on the environmental and 
geochemical data collected. Results indicate that on a seasonal scale, seawater temperatures rather than seawater $\mathrm{pH}$ control the calcifying fluid $\mathrm{pH}$. Further geochemical analysis suggests that this is related to the temperature dependency of the calcification rate. On a diurnal scale, model results suggest no elevated variability in calcifying fluid $\mathrm{pH}$ despite highly variable reef flat seawater conditions.

\section{Introduction}

Atmospheric $\mathrm{CO}_{2}$ levels have increased dramatically since the beginning of the industrial era, with one-quarter of the emitted $\mathrm{CO}_{2}$ being absorbed by the oceans (Friedlingstein et al., 2019). This process, known as ocean acidification $(\mathrm{OA})$, has lowered $\mathrm{pH}_{\mathrm{sw}}$ by approximately $0.1 \mathrm{pH}$ units compared to the preindustrial and reduced the seawater saturation state of the biologically important carbonate minerals calcite and aragonite $\left(\Omega_{\mathrm{sw}}\right.$; Bindoff et al., 2019). Ocean acidification is a significant environmental stressor for marine life as it is thought to affect the ability of many organisms to calcify. However, in coastal environments, such as coral reefs, $\mathrm{pH}_{\mathrm{sw}}$ is not only controlled by atmospheric $\mathrm{CO}_{2}$ but also is influenced by multiple drivers including tidal (Bates et al., 2010; Cyronak et al., 2018) and ecosystem-level processes (Smith, 1973; Gattuso et al., 1993; DeCarlo et al., 2017). Thus, the effect of OA on coastal environments is more complex and less predictable than in the open ocean (Duarte et al., 2013). Furthermore, corals do not precipitate $\mathrm{CaCO}_{3}$ directly from seawater, but instead from a medium located between calicoblastic cell membrane and skeleton, that is often referred to as calcifying fluid (Gattuso et al., 1999). Enzymatic processes elevate $\mathrm{pH}_{\mathrm{cf}}$ relative to ambient $\mathrm{pH}_{\mathrm{sw}}$ to facilitate aragonite precipitation (Constantz, 1986; McCulloch et al., 2017; Sevilgen et al., 2019). Thus, corals may exhibit some resilience to $\mathrm{OA}$ by upregulating $\mathrm{pH}_{\mathrm{cf}}\left(\mathrm{McCulloch}_{\mathrm{c}}\right.$ al., 2012). However, despite laboratory experiments showing $\mathrm{pH}_{\mathrm{cf}}$ correlates with $\mathrm{pH}_{\mathrm{sw}}$ (Hönisch et al., 2004; Krief et al., 2010; Venn et al., 2011), the sensitivity of coral $\mathrm{pH}_{\mathrm{cf}}$ to changes in ambient $\mathrm{pH}_{\mathrm{sw}}$ in natural environments is still unclear with some studies arguing that Porites corals maintain nearly constant $\mathrm{pH}_{\mathrm{cf}}$ despite variable ambient $\mathrm{pH}_{\mathrm{sw}}$ (i.e. $\mathrm{pH}_{\mathrm{cf}}$ homeostasis; Georgiou et al., 2015; Comeau et al., 2019), while others find $\mathrm{pH}_{\mathrm{cf}}$ is partially controlled by $\mathrm{pH}_{\mathrm{sw}}\left(\mathrm{D}^{\prime} \mathrm{Olivo}\right.$ et al., 2019; Guo, 2019) or that $\mathrm{pH}_{\mathrm{cf}}$ follows predominantly changes in $\mathrm{pH}_{\mathrm{sw}}$ (Kubota et al., 2017).

Most of these studies have analyzed Porites calcifying fluid carbonate chemistry variability on 
inter-decadal or seasonal time scales and only a few have focussed on shorter time scales, such as the diurnal variability (Cornwall et al., 2018; DeCarlo et al., 2019).

The main objective of this study is to quantify the sensitivity of $\mathrm{pH}_{\mathrm{cf}}$ upregulation to ambient seawater conditions in Porites, a coral genus that can be found on reef flats where $\mathrm{pH}_{\mathrm{sw}}$ naturally varies on both seasonal and diurnal scales. In this study, as in many others (Hönisch et al., 2004; Krief et al., 2010; Georgiou et al., 2015; Kubota et al., 2017; D'Olivo et al., 2019), the boron isotope ratio $\left(\delta^{11} \mathrm{~B}\right)$ of skeletal $\mathrm{CaCO}_{3}$ is used to infer $\mathrm{pH}_{\mathrm{cf}}(\mathrm{McCulloch}$ et al., 2018). To explore $\mathrm{pH}_{\mathrm{cf}}$ variability on a sub-monthly scale, variations of $\delta^{11} \mathrm{~B}$ are measured along the growth axis of one year of growth of a Porites sp. colony using laser ablation (LA) multi-collector inductively coupled plasma mass spectrometry (MC-ICP-MS; Standish et al., 2019). The data are coupled with measurements of other sclerochronological tracers, such as oxygen and carbon isotopes $\left(\delta^{18} \mathrm{O} / \delta^{13} \mathrm{C}\right)$, conventional $\delta^{11} \mathrm{~B}$ analysis with dissolution of samples (bulk), trace elements, and skeletal density. Calcifying fluid $\mathrm{pH}$ and other carbonate system parameters are calculated from coral $\delta^{11} \mathrm{~B}$ and $\mathrm{B} / \mathrm{Ca}$, and their sensitivity to changes in ambient $\mathrm{pH}_{\mathrm{sw}}$, temperature, and salinity are quantified. Furthermore, to estimate $\mathrm{pH}_{\mathrm{cf}}$ variability on a diurnal scale, a recent model that simulates coral $\mathrm{pH}_{\mathrm{cf}}$ upregulation from ambient environmental conditions (Guo, 2019) is applied. The model is optimized using seasonally resolved geochemical and instrumental data from this study and subsequently used to estimate $\mathrm{pH}_{\mathrm{cf}}$ variability on a diurnal scale from half-hourly resolved instrumental data.

\section{Materials and Methods}

\subsection{Study Site}

Kiritimati Island is a coral atoll in the equatorial central Pacific located at $1.9^{\circ} \mathrm{N} 157.4^{\circ} \mathrm{W}$ (Fig. 1) where inter-annual climate variability is dominated by the El Niño Southern Oscillation (Cobb et al., 2003) and ocean $\mathrm{pH}_{\mathrm{sw}}$ is one of the lowest in the Pacific at approximately 8.0 (Bakker et al., 2016). Average annual sea surface temperatures (SST) vary between $24^{\circ} \mathrm{C}$ during La Niña and $30^{\circ} \mathrm{C}$ during El Niño conditions (Woodroffe et al., 2003), and average rainfall rates are low, averaging $900 \mathrm{~mm} /$ year (1951-2006) and increase up to $3000 \mathrm{~mm} /$ year during El Niño events (Morrison \& Woodroffe, 2009). El Niño events also cause a pronounced positive sea level anomaly of up $0.3 \mathrm{~m}$ compared to La Niña conditions (Woodroffe et al., 2012). The tides at Cecile Peninsula follow a semi-diurnal cycle with a maximal tidal range of $1.12 \mathrm{~m}$. Kiritimati 
105 Island has been chosen as a study site due to its location close to the equator where the seasonal

106 variability in environmental parameters, such as seawater temperature, is expected to be small,

107 facilitating quantification of the effect of $\mathrm{pH}_{\mathrm{sw}}$ on $\mathrm{pH}_{\mathrm{cf}}$ upregulation. The study was conducted on

108 Cecile Peninsula (Fig. 1, coordinates of sampling sites see table S1 and S2) located in the South

109 of Kiritimati Island with only minor human influence (Walsh, 2011).

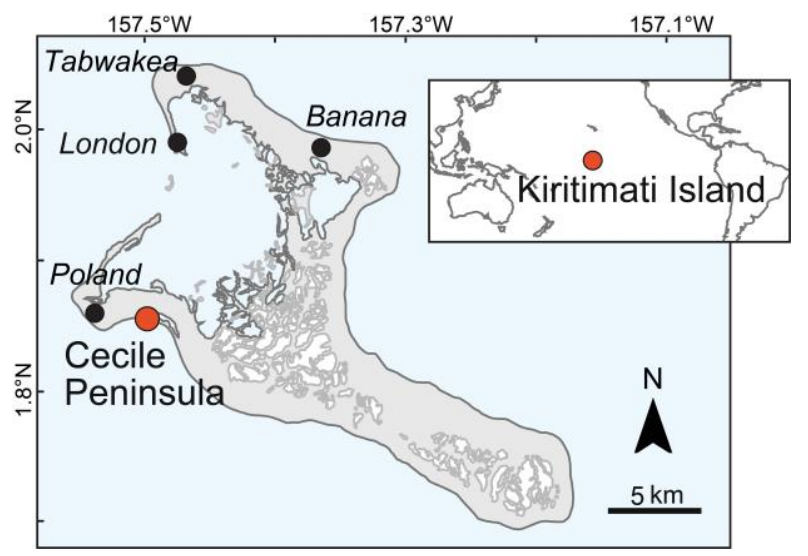

Figure 1. Map of Kiritimati Island with the location of the study site (Cecile Peninsula) and settlements. Also shown is the location of Kiritimati Island in the Pacific Ocean.

111 A $110 \mathrm{~cm}$ diameter microatoll colony of Porites sp. (Scoffin et al., 1978; Kench et al., 2019) on 112 the central reef flat at Cecile Peninsula was treated with alizarin red S (Lamberts, 1978) for 24 113 hours on the $14^{\text {th }}$ May 2017, and was collected after approximately one year of growth on the $11425^{\text {th }}$ May 2018. The treatment provided a red marker in the coral skeleton enabling detection and 115 subsequent sampling of one year of $\mathrm{CaCO}_{3}$ deposition (Fig. 2a). 

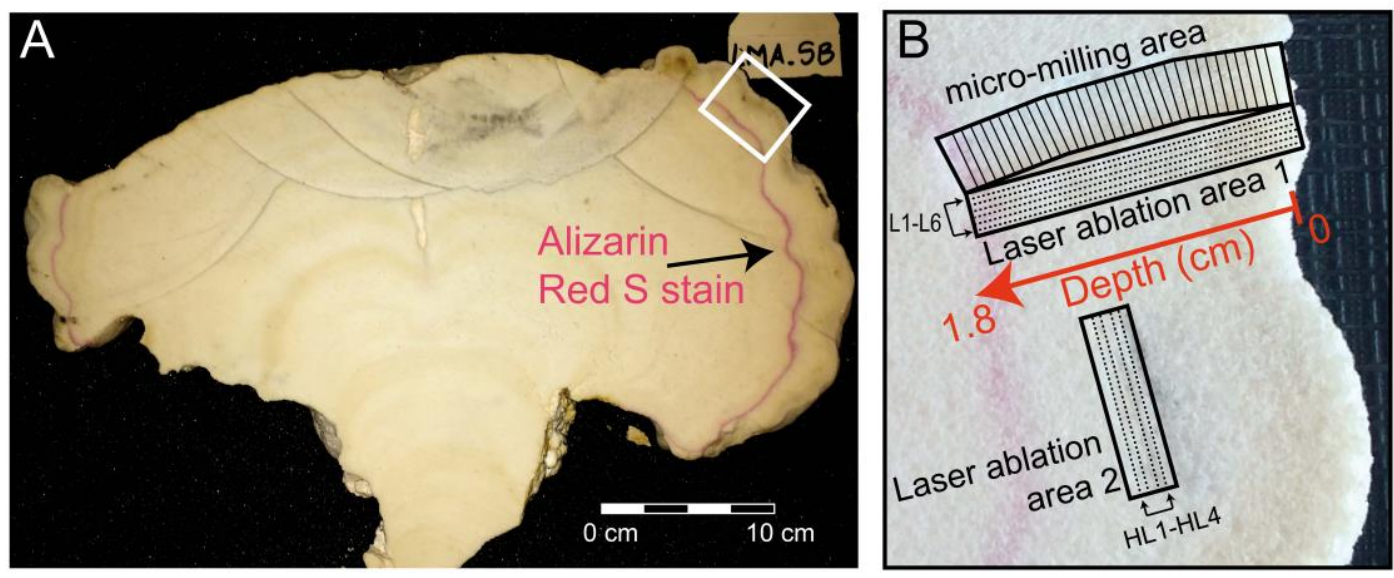

Figure 2. Section of Porites sp. colony with distinct red alizarin red S stain band (a). Areas in the annual growth layer analyzed: In the micro-milling area samples were removed with a micro-mill and dissolved prior to analysis (bulk analysis). In laser ablation area 1 (LAA-1) and 2 (LAA-2), material was analyzed in situ with LA-MC-ICP-MS (b).

Located $27 \mathrm{~m}$ from the stained coral, a sensor package consisting of a SeaFET $\mathrm{pH}$-sensor and CTD logger was deployed over the same period at approximately $0.5-1 \mathrm{~m}$ depth relative to mean sea level. The sensor package measured $\mathrm{pH}_{\mathrm{sw}}$, temperature, salinity, and water depth (pressure) at 30 min intervals. Flooding of the SeaFET $\mathrm{pH}$-sensor caused a gap in the $\mathrm{pH}_{\mathrm{sw}}$ data between the $6^{\text {th }}$ September 2017 and $9^{\text {th }}$ March 2018 when the damaged SeaFET pH-sensor was replaced by an identical model. Measurements of $\mathrm{pH}_{\mathrm{sw}}$ from the external SeaFET $\mathrm{pH}$ electrode were corrected for temperature and salinity using measurements from the CTD logger following Martz et al. (2010) and Miller et al. (2018). To evaluate differences in environmental conditions between reef flat and fore-reef, the sensor package was subsequently deployed on Cecile Peninsula fore-reef for 9 days between the $28^{\text {th }}$ of May and the $5^{\text {th }}$ of June 2018 at approximately $7 \mathrm{~m}$ depth relative to mean sea level. For determination of the total alkalinity of seawater $\left(\mathrm{TA}_{\mathrm{sw}}\right)$, seawater samples were collected from the reef flat in September 2017 and May 2018, and from the fore-reef in May 2018 (Table S1 in the Supplement). Seawater samples were collected during the day and night following Dickson et al. (2007). Titration of seawater samples to determine the TA $_{\text {sw }}$ was performed at the University of Otago in Dunedin, New Zealand. A portable pH-meter Orion A325 calibrated with TRIS and AMP buffer solutions was used for measurements of $\mathrm{pH}_{\mathrm{sw}}$, temperature, and salinity accompanying $\mathrm{TA}_{\mathrm{sw}}$ sampling. All $\mathrm{pH}$-measurements of this study are 
133 indicated on the total scale. Time series analysis of environmental data was conducted in $\mathrm{R}(\mathrm{R}$

134 Core Team, 2019).

135

136

137

138

139

140

141

142

143

144

145

146

147

148

149

150

151

152

153

154

155

156

157

158

159

160

161

\subsection{Sample Preparation, X-ray Densitometry, SEM}

At the end of the one-year growth experiment, the stained coral was cut with a saw, cleaned, and treated with sodium hypochlorite overnight. The specimen was later cut into $7 \mathrm{~mm}$ thick slices using a diamond wet saw. A micro-mill with a $1 \mathrm{~mm}$ diameter drill bit was then used to extract 34 sequential samples of $0.5-3.5 \mathrm{mg}$ of $\mathrm{CaCO}_{3}$ from the annual growth band. Of these samples, 32 covered $0.5 \mathrm{~mm}$, and 2 covered $1.0 \mathrm{~mm}$ of coral growth along the $1.8 \mathrm{~cm}$ long growth axis from the alizarin-stained band to the edge of the coral (Fig. 2b). Thus, one sample represents on average 11 days of calcification. Variations of skeletal density within the annual growth band were calculated from X-ray images (Carricart-Ganivet \& Barnes, 2007) recorded at Mercy Radiology Auckland, New Zealand (Fig. S1 in the Supplement). For this purpose, $7 \mathrm{~mm}$ thick cubes of coral aragonite with known density were used as standards enabling calibration of the X-ray image's greyscale against discrete density values using the program R (R Core Team, 2019). This was done for the area sampled by micro-milling (micro-milling area) and laser ablation area 1 (LAA-1) analyzed by LA-MC-ICP-MS.

\subsection{Geochemical Analysis}

A subsample of $0.05-0.07 \mathrm{mg} \mathrm{CaCO}_{3}$ was taken from the 34 micro-milled samples for $\delta^{18} \mathrm{O}$ and $\delta^{13} \mathrm{C}$ analyses at the Stable Isotope Mass Spectrometry Laboratory of the University of Southampton (UK). The remaining sample material was oxidatively cleaned by treatment with $30 \% \mathrm{H}_{2} \mathrm{O}_{2}$ buffered with $\sim 0.1 \mathrm{M} \mathrm{NH}_{4} \mathrm{OH}$ and dissolved in $\sim 0.15 \mathrm{M} \mathrm{HNO}_{3}$. Ten of the dissolved samples were then split into subsamples to permit trace element analysis $(\sim 10 \%)$ and boron isotope analysis ( $90 \%$ ). Both analyses were carried out at the University of Southampton. Trace element analysis ( $\mathrm{Li}, \mathrm{B}, \mathrm{Mg}, \mathrm{Al}, \mathrm{Mn}, \mathrm{Fe}, \mathrm{Cd}, \mathrm{Ba}, \mathrm{Nd}, \mathrm{U}$ ), performed on all 34 samples, employed a Thermo Scientific Element 2-XR MC-ICP-MS and followed methods published in Fowell et al. (2016). Prior to $\delta^{11} \mathrm{~B}$ analyses, boron was isolated from the carbonate matrix of 10 samples by ion-exchange chromatography using custom made $20 \mu \mathrm{l}$ Teflon columns filled with Amberlite IRA743 resin following Foster (2008) and Fowell et al. (2018). Boron isotope ratios were then measured on a Thermo Scientific Neptune MC-ICP-MS with mass bias correction by sample- 
standard bracketing with NIST SRM951 following Foster et al. (2013). Uncertainty in bulk $\delta^{11}$ B was determined following Rae et al. (2011), based on the long-term reproducibility of the JCp-1 reference material (Okai et al., 2002), and was on average $\pm 0.25 \%$ (2SD). The $\delta^{11} \mathrm{~B}$ of the JCp- 1 used in this study was $24.14 \%$, consistent with both the long term results from JCp-1 analysis in this laboratory and with results from other laboratories (24.25 \pm 0.22 ; Gutjahr et al., 2020). For trace element ratios, the analytical precision is $5 \%$ determined by the reproducibility of several in house standards (Henehan et al., 2015).

The study also adopts the novel use of LA-MC-ICP-MS to measure skeletal $\delta^{11} \mathrm{~B}$ (Thil et al., 2016; Sadekov et al., 2019; Standish et al., 2019). For this method, the coral slice was analyzed by a Thermo Scientific Neptune Plus MC-ICP-MS equipped with nine Faraday Cup detectors and a central ion counter coupled to a TwoVol2 cell of an Elemental Scientific Lasers NWR193 excimer laser ablation system at the University of Southampton, following a peak hopping approach that uses the ${ }^{11} \mathrm{~B} /{ }^{40} \mathrm{ArCa}^{4+}$ to correct for matrix interferences from scattered $\mathrm{Ca}$ ions (Standish et al. 2019). Data were collected using integrations of $2.194 \mathrm{~s}$ and idle times of $2 \mathrm{~s}$, and thus each data cycle was collected over a period of $8.388 \mathrm{~s}$. Accuracy and external reproducibility is demonstrated by repeat analyses of the in-house reference material PS69/3181, a cold water calcitic scleraxonian octocoral, which, over the course of this study, gave a mean value of $13.70 \pm 0.74 \%$ (all errors herein are $2 \mathrm{SD}$ ). This is consistent with a solution MC-ICPMS measurement of 13.83 $\pm 0.29 \%$ (Standish et al. 2019). Six laser ablation transects (L1-L6) were placed approximately 280-500 $\mu \mathrm{m}$ from the micro-milling transect (LAA-1, Fig. 2b). The LA transects themselves were spaced 280-420 $\mu \mathrm{m}$ apart, approximately parallel to each other. Four additional laser ablation transects each of $1 \mathrm{~cm}$ length were placed perpendicular to the coral growth axis (HL1-HL4) around $2 \mathrm{~cm}$ from LAA-1 (LAA-2, Fig. 2b) aiming to quantify the small-scale variability evident in LA-MC-ICP-MS derived $\delta^{11} \mathrm{~B}$ of approximately similar-aged $\mathrm{CaCO}_{3}$.

For all laser ablation analyses, a spot diameter of $140 \mu \mathrm{m}$ was used, sampling at a tracking speed of $5 \mu \mathrm{m} / \mathrm{s}$, a repetition rate of $12 \mathrm{~Hz}$, and energy density (power) of $6 \mathrm{~J} \mathrm{~cm}^{-2}$. With a total cycle time of $\sim 8.4$ seconds, one $\delta^{11} \mathrm{~B}$ data cycle corresponds to sample ablated over a distance of 182 $\mu \mathrm{m}$ along the LA transect. This translates into approximately 3.7 days of calcification. Along each LA transect, the distance between the centre points of ablated areas corresponding to 
consecutive data cycles is $\sim 40 \mu \mathrm{m}$, which translates into a sampling resolution of on average 0.8 days of calcification. However, subsequent smoothing of the data and averaging due to spot size reduces the effective resolution. Furthermore, the reproducibility of single LA data cycles is $\pm 2.44 \%$ o (2SD), based on analyses of the in-house reference material PS69/318-1, reducing our ability to resolve fine-temporal scale variability in $\delta^{11} \mathrm{~B}$.

The effect of an $\mathrm{H}_{2} \mathrm{O}_{2}$ treatment to oxidize any coral-organic material was explored for LA-MCICP-MS $\delta^{11} \mathrm{~B}$ by soaking the coral slice in $400 \mathrm{ml}$ of $20 \% \mathrm{H}_{2} \mathrm{O}_{2}$ solution for 24 hours after 3 (L1-L3) of the 6 laser ablation transects had been measured (LAA-1). All transects in LAA-2 were measured after $\mathrm{H}_{2} \mathrm{O}_{2}$ treatment.

Calculation of $\mathrm{pH}_{\mathrm{cf}}$ from $\delta^{11} \mathrm{~B}$ followed Foster and Rae (2016) using the isotopic fractionation constant from Klochko et al. (2006). For $\mathrm{pH}_{\mathrm{cf}}$ calculation, the value of the equilibrium constant for the dissociation of boric acid $\left(\mathrm{pK}_{\mathrm{B}}^{*}\right)$ was determined using daily averages of temperature and salinity recorded by the CTD logger. Calculation of carbonate parameters from B/Ca followed DeCarlo et al. (2018) using the partition coefficient from McCulloch et al. (2018). Calculation of seawater carbonate parameters was performed using the R-package seacarb (Gattuso et al., 2019). Time series analysis of geochemical data was conducted in R (R Core Team, 2019) and Past (Hammer et al., 2001).

\subsection{Numerical Modelling}

Calcifying fluid $\mathrm{pH}$ upregulation of Porites sp. colonies growing on Cecile Peninsula reef flat was simulated using a numerical model described in Guo (2019). This model simulates the effects of three key processes involved in coral $\mathrm{pH}_{\mathrm{cf}}$ upregulation, including enzymatic proton pumping $(\mathrm{P})$, carbon influx $(\mathrm{C})$, and the exchange of calcifying fluid with external seawater $(\mathrm{E})$, and predicts $\mathrm{pH}_{\mathrm{cf}}$ based on ambient seawater carbonate chemistry, temperature, and coral $\mathrm{P} / \mathrm{E}$ ratio. The model was optimized by determining the average $\mathrm{P} / \mathrm{E}$ ratio for the Porites sp. colony analyzed, based on the $\mathrm{pH}_{\mathrm{cf}}$ data derived from our 10 bulk $\delta^{11} \mathrm{~B}$ measurements where a sample represents on average 11 days of calcification, as well as seawater carbonate chemistry parameters and temperature data averaged over equivalent time periods. Specifically, seawater carbonate chemistry parameters, such as dissolved inorganic carbon $\left(\mathrm{DIC}_{\mathrm{sw}}\right)$ or $\Omega_{\mathrm{sw}}$, were estimated from SeaFET $\mathrm{pH}$-sensor measurements of $\mathrm{pH}_{\mathrm{sw}}$, CTD recordings of temperature and salinity, and average $\mathrm{TA}_{\mathrm{sw}}$ determined from reef flat seawater samples collected in September 
2017 and May 2018, during day and night (Table S1). In the time interval when no SeaFET pHsensor data were available, average values of seawater carbonate chemistry were used for optimizing the coral $\mathrm{P} / \mathrm{E}$ ratio.

The optimized coral P/E value was then combined with high resolution (30 minute) recordings of $\mathrm{pH}_{\mathrm{sw}}$ and temperature, as well as similarly resolved estimates of other seawater carbonate chemistry parameters to predict $\mathrm{pH}_{\mathrm{cf}}$ upregulation on a diurnal scale. Specifically, $\mathrm{DIC}$ sw and $\Omega_{\mathrm{sw}}$ were estimated from 30 minutes measurements of $\mathrm{pH}_{\mathrm{sw}}$, temperature, salinity, and average $\mathrm{TA}_{\mathrm{sw}}$ from day and night measurements in September 2017 and May 2018 on Cecile Peninsula reef flat (Table S1), as it was not possible to measure other carbonate system parameters with the same resolution as $\mathrm{pH}_{\mathrm{sw}}$. Sensitivity tests of model predictions in $\mathrm{pH}_{\mathrm{cf}}$ to changes in $\mathrm{TA}_{\mathrm{sw}}$ resulted in a sensitivity of $-0.010 \pm 0.001 \mathrm{pH}$ units per $100 \mu \mathrm{mol} \mathrm{kg}^{-1}$ increase in $\mathrm{TA}_{\mathrm{sw}}$. Thus, the small variability in $\mathrm{TA}_{\mathrm{sw}}$ observed at the study site has no substantial effect on model predictions in $\mathrm{pH}_{\mathrm{cf}}$. For example, $\mathrm{TA}_{\mathrm{sw}}$ varied by $43 \pm 143 \mu \mathrm{mol} \mathrm{kg}^{-1}$ between September 2017 and May 2018, while the mean diurnal range in $\mathrm{TA}_{\mathrm{sw}}$ recorded was $49 \pm 65 \mu \mathrm{mol} \mathrm{kg}{ }^{-1}$ consistent with the diurnal range in $\mathrm{TA}_{\mathrm{sw}}$ reported previously at similar water depths, e.g., $43 \pm 39 \mu \mathrm{mol} \mathrm{kg}^{-1}$ (Zhang et al., 2013), $23 \pm 7 \mu \mathrm{mol} \mathrm{kg}{ }^{-1}$, and $71 \pm 23 \mu \mathrm{mol} \mathrm{kg}^{-1}$ (Lantz et al., 2014).

The physiological processes simulated in the model operate over a scale of seconds and thus the model is well capable of simulating diurnal variations in $\mathrm{pH}_{\mathrm{cf}}$. Note, however, that the model $\mathrm{P} / \mathrm{E}$ ratio is optimized based on seasonal variations in $\mathrm{pH}_{\mathrm{sw}}$ and temperature, and this is assumed constant throughout the model simulation. Some culturing experiments under constant $\mathrm{pH}_{\mathrm{sw}}$ and temperature conditions showed that $\mathrm{pH}_{\mathrm{cf}}$ is reduced in the absence of light, which is likely related to the light dependent photosynthetic activity of the zooxanthellae (Al-Horani et al., 2002; Venn et al., 2011; Sevilgen et al., 2019). Such physiological processes that occur at the diurnal scale and are largely independent of seawater conditions are not included in the model due to the assumption of constant model parameters across different time scales.

\section{Results}

\subsection{Environmental Monitoring}

Field measurements of $\mathrm{pH}_{\mathrm{sw}}$ showed that at Cecile Peninsula reef flat average $\mathrm{pH}_{\mathrm{sw}}$ is relatively stable throughout the year with slightly lower values in spring 2018 than during spring and 
251 summer 2017 (Fig. 3c). During the first period of $\mathrm{pH}_{\mathrm{sw}}$ measurements $\left(14^{\text {th }}\right.$ May $-6^{\text {th }}$ September 252 2017) average $\mathrm{pH}_{\mathrm{sw}}$ was $7.99 \pm 0.14$ and during the second period ( $9^{\text {th }}$ March $-25^{\text {th }}$ May 2018)

253 average $\mathrm{pH}_{\mathrm{sw}}$ was 7.96 \pm 0.20 . However, a relatively large diurnal $\mathrm{pH}$-cycle exists on the reef flat, 254 with $\mathrm{pH}_{\mathrm{sw}}$ ranging up to $8.37 \pm 0.01$ during the day with a minimum value of $7.65 \pm 0.01$ during the 255 night (both measured on $4^{\text {th }}$ April 2018, Fig. 3c and 4a) and a mean diurnal $\mathrm{pH}_{\mathrm{sw}}$ range $\left(\Delta \mathrm{pH}_{\mathrm{sw}}\right)$ 256 of $0.29 \pm 0.24 \mathrm{pH}$ units.

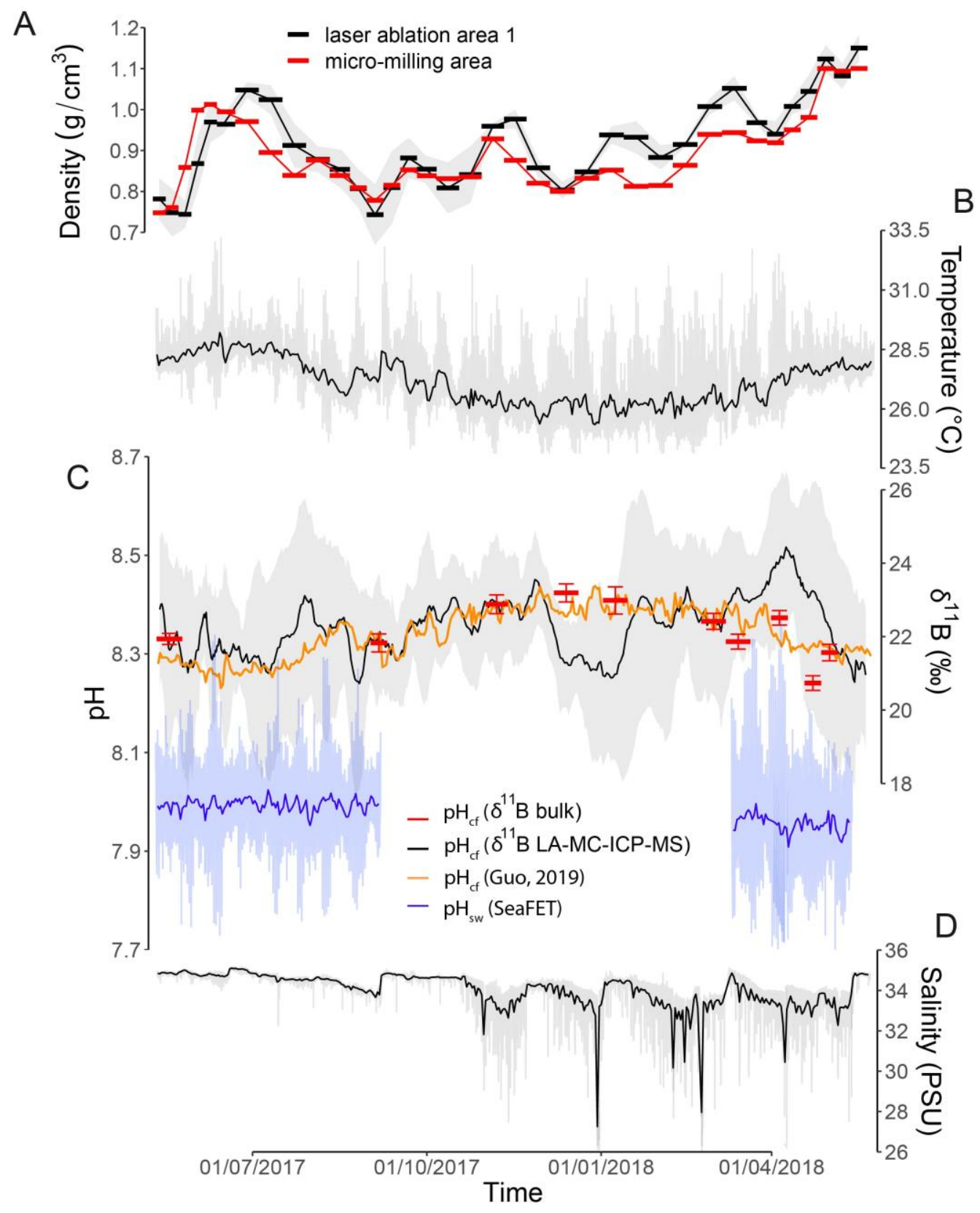


Figure 3. Skeletal density derived from X-ray densitometry (a), daily averaged seawater temperature from CTD logger (b), $\mathrm{pH}_{\mathrm{cf}}$ reconstructed from $\delta^{11} \mathrm{~B}$ (LA-MC-ICP-MS plotted as an 8 point running mean, black) and modelled following Guo (2019, orange), $\mathrm{pH}_{\mathrm{sw}}$ recorded by SeaFET $\mathrm{pH}$-sensor (c) with daily averages (dark blue) and measured with a $30 \mathrm{~min}$ resolution (light blue), as well as daily averaged seawater salinity (d), grey lines in plot of temperature and salinity are 30 min measurements, and the grey area in $\delta{ }^{11} \mathrm{~B}$ indicates standard deviation.

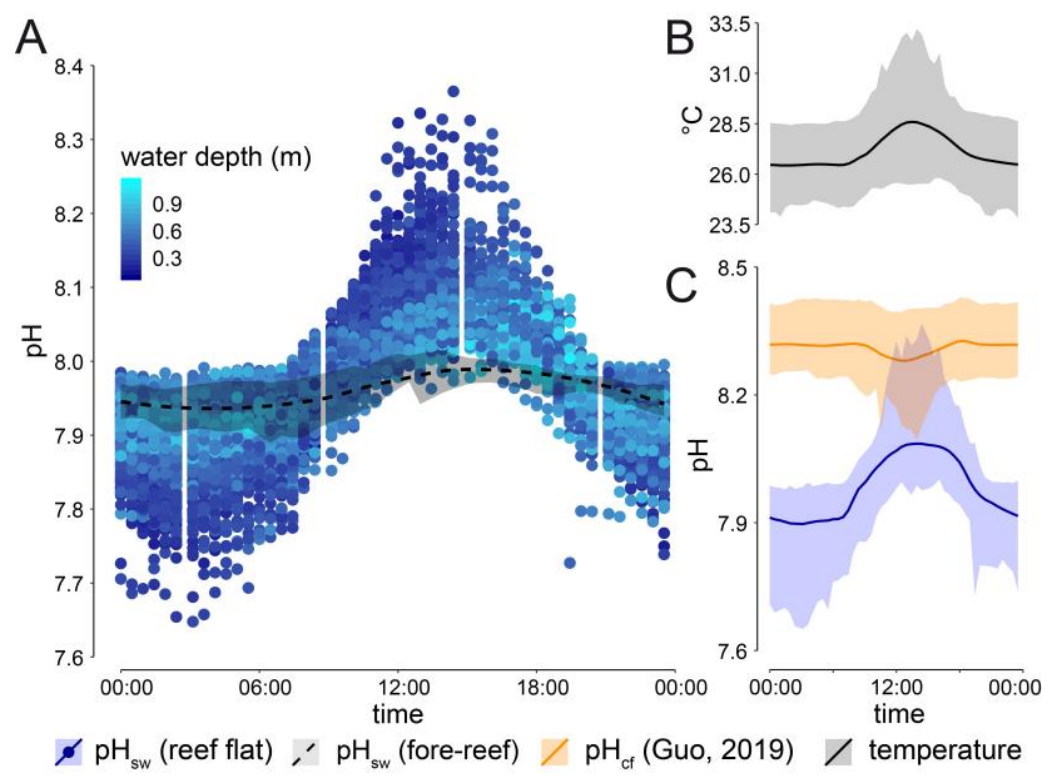

Figure 4. Diurnal $\mathrm{pH}_{\mathrm{sw}}$-cycle and water depth relative to the position of CTD logger. The average $\mathrm{pH}_{\mathrm{sw}}$ measured on the fore-reef is indicated as a dashed line with maximum and minimum $\mathrm{pH}_{\mathrm{sw}}$ measured at a given time contoured as greyed area (a). Diurnal temperature cycle with greyed area indicating minimum and maximum values recorded at a specific time (b). Diurnal cycle of $\mathrm{pH}_{\mathrm{cf}}$ (orange) from numerical modelling and $\mathrm{pH}_{\mathrm{sw}}$ (blue) as recoded by SeaFET $\mathrm{pH}$-sensor. Transparent areas indicate the minimum and maximum values recorded at a given time (c). average reef flat $\mathrm{pH}$ recorded over the one-year period, and very close to average reef flat $\mathrm{pH}$ of 
$7.94 \pm 0.17$ recorded during the 9 days of sampling before moving the SeaFET $\mathrm{pH}$-sensor to the fore-reef. However, the diurnal $\mathrm{pH}_{\mathrm{sw}}$ range was substantially lower on the fore-reef with $\Delta \mathrm{pH}_{\mathrm{sw}}=$ $0.07 \pm 0.05$ over the 9 days sampling interval (Fig. $4 \mathrm{a}$ ). The highest $\mathrm{pH}_{\mathrm{sw}}$ recorded on the fore-reef was 8.02 \pm 0.01 and the lowest was $7.89 \pm 0.01$. Day and night measurements of $\mathrm{TA}_{\mathrm{sw}}$, that showed only little variability, $\mathrm{pH}_{\mathrm{sw}}$ temperature and salinity on the reef flat and fore-reef were used to calculate other seawater carbonate parameters (Table S1). On the reef flat, DIC $\mathrm{sw}_{\mathrm{sw}}$ and $\Omega_{\mathrm{sw}}$ revealed a similar diurnal divergence from daily average as $\mathrm{pH}_{\mathrm{sw}}$, but notably, daily averages on the reef flat for these other carbonate system parameters were also similar to values on the forereef.

Reef flat CTD seawater temperature measurements revealed an annual average of $27.1 \pm 2.6^{\circ} \mathrm{C}$ and a clear seasonal pattern with a maximum daily average value of $29.2 \pm 3.2^{\circ} \mathrm{C}$ recorded during summer $\left(14^{\text {th }}\right.$ June 2017$)$ and a minimum of $25.3 \pm 1.0^{\circ} \mathrm{C}$ during winter $\left(28^{\text {th }}\right.$ December 2017 , Fig. 3b). Mean temperature on the fore-reef between the $28^{\text {th }}$ May and $5^{\text {th }}$ June 2018 was $27.7 \pm 0.3^{\circ} \mathrm{C}$, comparable to that recorded on the reef flat between the $3^{\text {rd }}$ and $11^{\text {th }}$ of May $\left(27.8 \pm 1.17^{\circ} \mathrm{C}\right)$. The diurnal temperature range observed on the fore-reef was $0.3 \pm 0.2^{\circ} \mathrm{C}$, substantially lower than that on the reef flat which exhibited a diurnal temperature range of $1.7 \pm 1.2^{\circ} \mathrm{C}$ between the $3^{\text {rd }}$ and $11^{\text {th }}$ May 2018 .

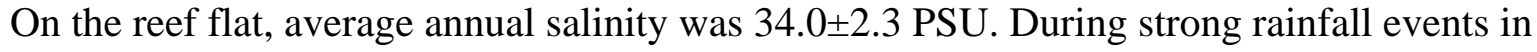
winter and spring, average daily salinity decreased to 27.3 \pm 1.1 PSU (30 ${ }^{\text {th }}$ December 2017 ), indicating the formation of a temporary low-salinity layer (Fig. 4d). Mean salinity recorded on the fore-reef over the 9 days sampling period was $34.9 \pm 0.08$ PSU that is only slightly higher than that measured on the reef flat between the $3^{\text {rd }}$ to $11^{\text {th }}$ of May on the reef flat (34.8 \pm 2.0 PSU).

\subsection{Geochemical Analysis and X-ray Densitometry}

It is known from previous studies that due to low rainfall rates on Kiritimati Island coral $\delta^{18} \mathrm{O}$ closely follows SST with little effect of seawater salinity (McGregor et al. 2011). Thus, the alignment of coral $\delta^{18} \mathrm{O}$ with seawater temperatures recorded by the CTD logger enabled the construction of an age-depth model for the annual growth band (Fig. S5). 
Values of $\delta^{11} \mathrm{~B}$ measured with conventional dissolution (bulk analysis) remained relatively stable along the annual growth band with an average of $22.09 \pm 1.46 \%$ and a variance of $0.53 \%$ (Fig. $3 \mathrm{c})$. The mean of the 6 laser ablation transects of LAA-1 revealed a similar average $\delta^{11} \mathrm{~B}$ of $22.20 \pm 1.64 \%$, but with large variation around this value from $16.02 \%$ o to $27.57 \%$ and a variance of $2.16 \%$ (Fig. 3c). The good agreement in average $\delta^{11} \mathrm{~B}$ between both methods validates the accuracy of LA-MC-ICP-MS measurements of $\delta^{11} \mathrm{~B}$. The apparently higher $\delta^{11} \mathrm{~B}$ from LA-MC-ICP-MS in the outermost $5 \mathrm{~mm}$ of the annual band might result from tissue layer organic matter residues which are also seen to reduce $\delta^{13} \mathrm{C}$ and $\mathrm{U} / \mathrm{Ca}$, as well as increase $\mathrm{Cd} / \mathrm{Ca}$ in this area (Fig. S2). However, the treatment of samples with $\mathrm{H}_{2} \mathrm{O}_{2}$ to remove organic constituents did not seem to affect the results (Fig. S3). Laser ablation measurements before the sample was treated with $\mathrm{H}_{2} \mathrm{O}_{2}$ (transect L1, L2, and L3) resulted in a mean $\delta^{11} \mathrm{~B}$ of $22.01 \pm 2.16$ \%o with a variance of $1.59 \%$. Similarly, measurements after $\mathrm{H}_{2} \mathrm{O}_{2}$ treatment (transect L4, L5, and L6) revealed a mean $\delta^{11} \mathrm{~B}$ of $22.39 \pm 2.52 \%$ with a variance of $2.45 \%$.

Results of LA-MC-ICP-MS $\delta^{11} \mathrm{~B}$ analysis along the four transects perpendicular to the coral's growth axis (LAA-2, Fig. 2b) reflects the $\delta^{11} \mathrm{~B}$ variability in $\mathrm{CaCO}_{3}$ that was precipitated nearly synchronously (Fig. S4). Therefore, the observed variabilities in $\delta^{11} \mathrm{~B}$ along these transects are not simply due to variations in ambient seawater conditions, but likely result from sampling different components of the coral skeleton macrostructure with variable $\delta^{11} \mathrm{~B}$. Results show that the variance observed in $\delta^{11} \mathrm{~B}$ transects of LAA-2 was around 50\% lower (HL1: $\sigma^{2}=1.92 \%$, HL2: $\sigma^{2}=2.67 \%$, HL3: $\sigma^{2}=1.18 \%$, HL4: $\sigma^{2}=1.47 \%$ ) than in transects from LAA-1 (L1: $\sigma^{2}$ $=2.13 \%$, L2: $\sigma^{2}=3.02 \%$, L3: $\sigma^{2}=3.76 \%$, L4: $\sigma^{2}=4.5 \%$, L5: $\sigma^{2}=3.87 \%$, L6: $\sigma^{2}=2.42$ $\%$ ). This suggests that approximately half of the variability in each of the $\delta^{11} \mathrm{~B}$ transects from LAA-1 results from sampling different components of the coral skeleton macrostructure. Similar $\delta^{11} \mathrm{~B}$ heterogeneities have been found in other coral $\delta^{11} \mathrm{~B}$ LA-MC-ICP-MS studies (Chalk et al., 2021) and are likely linked to spatial variations of $\mathrm{pH}_{\mathrm{cf}}$ in the coral skeleton as shown in studies using pH-sensitive dyes or microelectrodes (Venn et al. 2011, Cai et al. 2016, Sevilgen et al. 2019). These macrostructural heterogeneities in skeletal $\delta^{11} \mathrm{~B}$ may also explain the short-term differences between bulk and LA-MC-ICP-MS derived $\delta^{11} \mathrm{~B}$ in some intervals (Fig. 3c), as well as some of the differences between individual LA $\delta^{11} \mathrm{~B}$ transects L1-6. The remaining variability within and across the $\delta^{11} \mathrm{~B}$ transects can, at least in part, be attributed to the relatively low precision of the LA-MC-ICP-MS measurements here compared to solution-based approaches. 
Skeletal density variations measured for micro-milling area and LAA-1 (Fig. 3a) showed a high level of agreement $\left(\mathrm{r}^{2}=0.72, \mathrm{p}<0.01, \mathrm{n}=36\right)$. Estimated skeletal density was in the lower range of previously reported values for Porites (Tanzil et al. 2016, Tortolero-Langarica et al. 2016, Mollica et al. 2018) with on average $0.89 \pm 0.19 \mathrm{~g} \mathrm{~cm}^{-3}$ (micro-milling area), $0.91 \pm 21 \mathrm{~g} \mathrm{~cm}^{-3}$ (LLA-1) respectively. The highest density values were measured at the edge of the annual band $\left(1.15 \mathrm{~g} \mathrm{~cm}^{-3}\right)$ and another local maximum at 15.75 to $14.25 \mathrm{~mm}$ depth $\left(1.00 \mathrm{~g} \mathrm{~cm}^{-3}\right)$. The lowest values were found at the base and of the annual band and at $12 \mathrm{~mm}$ depth $\left(0.75 \mathrm{~g} / \mathrm{cm}^{-3}\right)$.

\subsection{Numerical Modelling}

Theoretical modeling showed that the coral's physiological regulation of $\mathrm{pH}_{\mathrm{cf}}$ is best represented by the interplay between enzymatic proton pumping $(\mathrm{P})$ and the exchange of calcifying fluid with external seawater (E), i.e. a colony specific P/E ratio (Guo, 2019). Thus, the numerical model of $\mathrm{pH}_{\mathrm{cf}}$ upregulation (Guo, 2019) was first optimized to determine the average P/E ratio specific to the Porites sp. specimen employed in this study (see section 2.5). With this optimized $\mathrm{P} / \mathrm{E}$ ratio, this model successfully reproduced the $\mathrm{pH}_{\mathrm{cf}}$ derived from bulk $\delta^{11} \mathrm{~B}$ measurements (Fig. 3c) and predicts only limited diurnal $\mathrm{pH}_{\mathrm{cf}}$ variability (Fig. 4c). The model predicted a mean diurnal range in $\mathrm{pH}_{\mathrm{cf}}$ of $\Delta \mathrm{pH}_{\mathrm{cf}}=0.07 \pm 0.08$ with a maximum $\Delta \mathrm{pH}_{\mathrm{cf}}$ of $0.21\left(1^{\text {st }}\right.$ April 2018) and a minimum of $0.03\left(21^{\text {st }}\right.$ July 2017). Notably, this is substantially lower than the diurnal range in ambient $\mathrm{pH}_{\mathrm{sw}}$ of on average $0.29 \pm 0.24 \mathrm{pH}$ units.

\section{Discussion}

\subsection{Variability in Reef Flat Environmental Conditions}

On a seasonal scale, variations of seawater temperature affect $\mathrm{pH}_{\mathrm{sw}}$ through the temperature dependency of dissociation constants. However, only a weak correlation $\left(\mathrm{r}^{2}=0.16, \mathrm{p}<0.01, \mathrm{n}=\right.$ 179) between daily averages of $\mathrm{pH}_{\mathrm{sw}}$ on the reef flat and seawater temperatures was found (Fig. $3 \mathrm{~b}$ and c, Fig. S6a). Due to the failure of the SeaFET pH-sensor, it was not possible to analyze a full seasonal cycle and this limitation may be obscuring any correlations. On the other hand, seasonal temperature variations at Kiritimati Island were low $\left(4^{\circ} \mathrm{C}\right)$ and thus the effect of temperature is likely superseded by other environmental factors. Across the monitoring period that $\mathrm{pH}_{\mathrm{sw}}$ was recorded, daily averages of $\mathrm{pH}_{\mathrm{sw}}$ and salinity showed the highest degree of correlation $\left(r^{2}=0.56, p<0.01, n=179\right.$, Fig. S6b). Heavy rainfall events in winter 2017/2018 
and spring 2018 caused the formation of a low-salinity layer on the reef flat and this dilution of seawater by meteoric water explains the lower $\mathrm{pH}_{\mathrm{sw}}$ values recorded during spring 2018 compared to spring and summer 2017 (0.04 pH units, Fig. 3c and d).

Agreement between daily averages of $\mathrm{pH}_{\mathrm{sw}}$ measured with the SeaFET $\mathrm{pH}$-sensor (Fig. 4a), and the other carbonate system parameters calculated from $\mathrm{TA}_{\mathrm{sw}}$ and portable $\mathrm{pH}$-meter measurements between the reef flat and fore-reef (Table S1), indicates that average seawater conditions on the reef flat are influenced by, and reflect, off reef conditions. However, the amplitude of the diurnal $\mathrm{pH}_{\mathrm{sw}}$ and temperature cycles on the reef flat exceeded those on the forereef by half an order of magnitude (Fig. 4a), as reported previously in other reef systems (Cyronak et al., 2019). A number of studies have detailed that the balance between Net Ecosystem Productivity (NEP) and Net Ecosystem Calcification (NEC) drives the diurnal $\mathrm{pH}_{\mathrm{sw}}$ cycle on the reef (Smith, 1973; Gattuso et al., 1993; DeCarlo et al., 2017). NEP describes the rates of photosynthesis and respiration that occur on the reef, whereby photosynthesis removes $\mathrm{CO}_{2}$ from the seawater increasing $\mathrm{pH}_{\mathrm{sw}}$, and respiration releases $\mathrm{CO}_{2}$ reducing $\mathrm{pH}_{\mathrm{sw}}(\mathrm{Cyronak}$ et al., 2018). NEC is controlled by the rate of calcification and dissolution whereby calcification releases $\mathrm{CO}_{2}$ lowering $\mathrm{pH}_{\mathrm{sw}}$ and dissolution consumes $\mathrm{CO}_{2}$ increasing $\mathrm{pH}_{\mathrm{sw}}$. As photosynthesis dominates during the day, and respiration during the night, $\mathrm{pH}_{\mathrm{sw}}$ oscillates diurnally (Fig. $3 \mathrm{c}$ and 4a). During days with elevated solar irradiance photosynthesis is stimulated and the maximum of the diurnal $\mathrm{pH}_{\mathrm{sw}}$ cycle tends towards higher values than on days with cloud cover. Elevated solar irradiance also leads to elevated seawater temperatures. A significant positive correlation $\left(\mathrm{r}^{2}=\right.$ $0.40, \mathrm{p}<0.01, \mathrm{n}=179$ ) between average $\mathrm{pH}_{\mathrm{sw}}$ and temperature, measured between $12 \mathrm{pm}$ and 4 pm when the diurnal $\mathrm{pH}_{\mathrm{sw}}$ cycle peaks (Fig. S7), confirms this dependency for the reef flat (Fig. $\mathrm{S} 7 \mathrm{a})$. However, the main driver of the diurnal $\mathrm{pH}_{\mathrm{sw}}$ cycle's magnitude on the reef flat appears to be the tidal cycle (Shaw et al., 2012; Chan \& Eggins, 2017). The water level on the reef flat determines the seawater residence time and thus how much seawater with low (night) or high (day) $\mathrm{pH}_{\mathrm{sw}}$ levels remains on the reef flat or is removed in exchange with seawater off reef with more moderate $\mathrm{pH}_{\mathrm{sw}}$. If low tide occurs during the maximum and minimum of the diurnal $\mathrm{pH}_{\mathrm{sw}}$ cycle, which is at approximately $12 \mathrm{pm}$ to $4 \mathrm{pm}$, and 2 am respectively, the products of NEP and NEC accumulate in a smaller volume of water. This amplifies the diurnal $\mathrm{pH}_{\mathrm{sw}}$ range by further increasing $\mathrm{pH}_{\mathrm{sw}}$ during the day and lowering $\mathrm{pH}_{\mathrm{sw}}$ during the night (Fig. 4a). This is evident by a negative correlation between averaged $\mathrm{pH}_{\mathrm{sw}}$ and water depth during the day time (12 pm to 4 
378

379

380

381

382

383

384

385

386

387

388

389

$\mathrm{pm})$ in the time interval $14^{\text {th }}$ May $-6^{\text {th }}$ September $2017\left(\mathrm{r}^{2}=0.47, \mathrm{p}<0.01, \mathrm{n}=119\right)$, as well as in the in the time interval $9^{\text {th }}$ March $-25^{\text {th }}$ May $2018\left(\mathrm{r}^{2}=0.53, \mathrm{p}<0.01, \mathrm{n}=63\right)$, and the positive correlation at night time $(2 \mathrm{am})$ in the time interval $14^{\text {th }}$ May $-6^{\text {th }}$ September $2017\left(\mathrm{r}^{2}=\right.$ $0.39 \mathrm{p}<0.01, \mathrm{n}=119)$, and in the time interval $9^{\text {th }}$ March $-25^{\text {th }}$ May $2018\left(\mathrm{r}^{2}=0.51, \mathrm{p}<0.01, \mathrm{n}\right.$ $=63$ ), respectively (Fig. S8). Finally, the influences of low water levels on $\mathrm{pH}_{\mathrm{sw}}$ are most evident during spring tides and the smallest during neap tides. Hence, daily maxima and minima values of $\mathrm{pH}_{\mathrm{sw}}$ oscillate with a periodicity of 15 days that is equivalent to the average periodicity of the occurrence of spring tides or half a synodic month (Fig. 3c, Fig. 5a, Fig. S9a-d). Elevated day time (12 pm to $4 \mathrm{pm}$ ) seawater temperatures occur with a similar periodicity as smaller volumes of water during low spring tides warm up quicker (Fig. 3b, Fig. 5b, Fig. S9e). However, the effect of spring and neap tides is less significant in time series of seawater temperatures than of $\mathrm{pH}_{\mathrm{sw}}$.
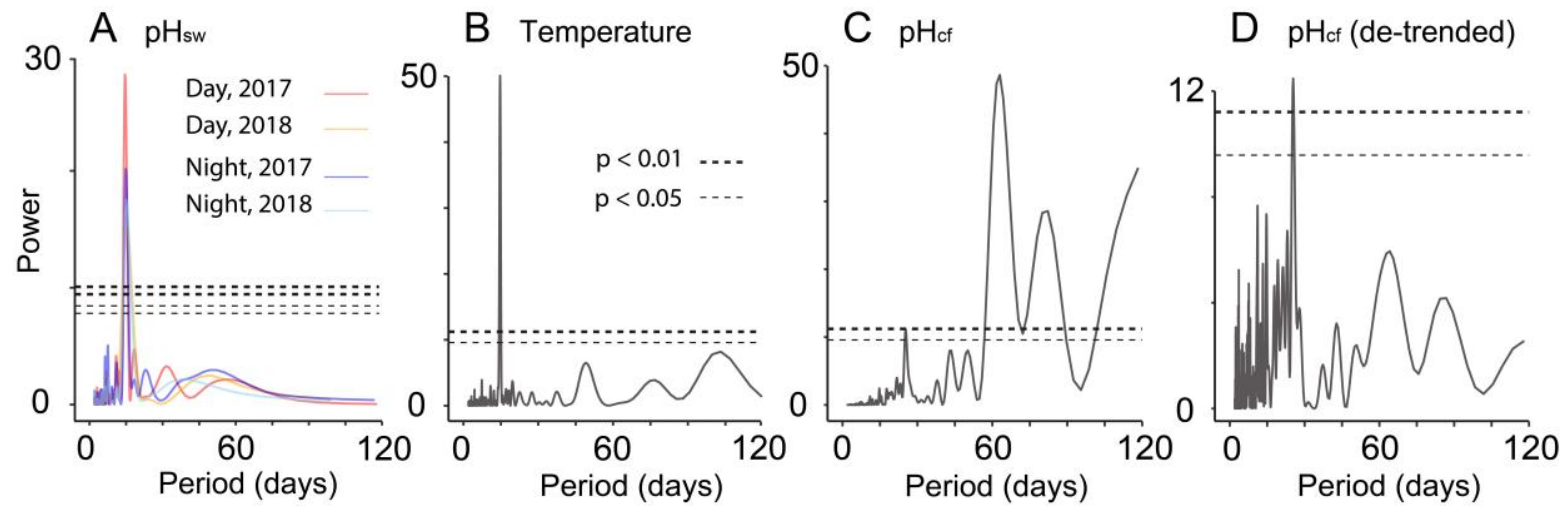

Figure 5. The amplitude of the reef flat $\mathrm{pH}_{\mathrm{sw}}$ and temperature cycle oscillate with a 15 days periodicity: Results of spectral analysis of day time (12-4 pm) and night time (2 am) $\mathrm{pH}_{\mathrm{sw}}$ (a) and day time (12-4 pm) seawater temperature (b). No similar periodicity was found in time series of LA-MC-ICP-MS $\delta^{11} \mathrm{~B}$ derived $\mathrm{pH}_{\mathrm{cf}}(\mathrm{c})$ or the similar de-trended (differenced) time series $(d)$. Confidence lines are indicated as thick $(\mathrm{p}<0.01)$ and thin $(\mathrm{p}<0.05)$ dashed lines whereas in (a) confidence lines of day and night 2017 overlap at power $=10.08(\mathrm{p}<0.01)$ and power $=8.44(\mathrm{p}<0.05)$, as well as the confidence lines of day and night 2018 at power $=9.44(\mathrm{p}$ $<0.01)$ and power $=7.81(\mathrm{p}<0.05)$.

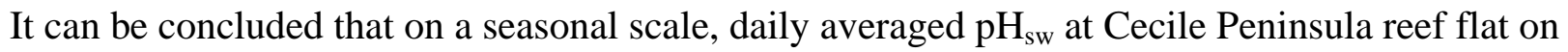
Kiritimati Island appears to remain relatively stable, likely following off reef trends, with the 
392 long-term $\mathrm{pH}_{\mathrm{sw}}$ variability being caused by large rainfall events diluting the seawater and causing

393 a reduction in $\mathrm{pH}_{\mathrm{sw}}$. On the diurnal cycle, the occurrence of maxima and minima $\mathrm{pH}_{\mathrm{sw}}$, and

394 maxima of seawater temperatures followed the 15 days spring-neap tidal cycle and associated

395 variations of sea level.

$396 \quad 4.2$ Variability in $\mathrm{pH}_{\mathrm{cf}}$ Upregulation

397 In the time intervals when both $\mathrm{pH}_{\mathrm{sw}}$ and $\mathrm{pH}_{\mathrm{cf}}$ data are available, the coral upregulated $\mathrm{pH}_{\mathrm{cf}}$ on 398 average by $0.33 \mathrm{pH}$ units for bulk $\delta^{11} \mathrm{~B}$ and $0.37 \mathrm{pH}$ units for LA-MC-ICP-MS $\delta^{11} \mathrm{~B}$, respectively 399 (Fig. 3c). This is similar to the level of $\mathrm{pH}_{\mathrm{cf}}$ upregulation reported for Porites by McCulloch et 400 al. (2017) and in the same range as other studies (Hönisch et al., 2004; Krief et al., 2010; 401 Georgiou et al., 2015; Wall et al., 2016). In addition to $\mathrm{pH}_{\mathrm{cf}}$, estimates based on $\mathrm{B} / \mathrm{Ca}$ ratios 402 suggest calcifying fluid dissolved inorganic carbon $\left(\mathrm{DIC}_{\mathrm{cf}}\right)$ was elevated by a factor of 2.4, 403 calcifying fluid total alkalinity $\left(\mathrm{TA}_{\mathrm{cf}}\right)$ by 2.5 , and calcifying fluid aragonite saturation state $\left(\Omega_{\mathrm{cf}}\right)$ 404 by 4.2 compared to ambient seawater conditions on the reef flat (Fig. S10, Table S1). These 405 results are also in the range reported in a previous study (Comeau et al., 2017).

406 On a seasonal scale, $\delta^{11} \mathrm{~B}$ derived coral $\mathrm{pH}_{\mathrm{cf}}$ did not show any significant correlation with 407 variations of $\mathrm{pH}_{\mathrm{sw}}$ as recorded by the SeaFET $\mathrm{pH}$-sensor (Fig. 6a). Indeed, in the time interval $9^{\text {th }}$ 408 March $-25^{\text {th }}$ May 2018 where $\mathrm{pH}_{\mathrm{sw}}$ values were slightly reduced (-0.04 $\mathrm{pH}$ units) due to the 409 formation of a low-salinity layer on the reef flat, laser ablation $\delta^{11} \mathrm{~B}$ derived $\mathrm{pH}_{\mathrm{cf}}$ remained 410 slightly elevated $(+0.09 \mathrm{pH}$ units, Fig. 3c). Seawater temperature appeared to be the main driver 411 of observed $\mathrm{pH}_{\mathrm{cf}}$ variations with $\mathrm{r}^{2}=0.58(\mathrm{p}<0.01, \mathrm{n}=10)$ between $\mathrm{pH}_{\mathrm{cf}}$ calculated from bulk $412 \delta^{11} \mathrm{~B}$ and seawater temperatures (Fig. 3b and c, Fig. 6b). A predominant control of ambient 413 seawater temperatures on Porites $\mathrm{pH}_{\mathrm{cf}}$ upregulation on a seasonal scale is in accordance with 414 other recent studies (McCulloch et al., 2017; Ross et al., 2017; Guo, 2019), as well as those that 415 revealed a limited sensitivity of Porites $\mathrm{pH}_{\mathrm{cf}}$ upregulation to seasonal variations in $\mathrm{pH}_{\mathrm{sw}}$ 416 (Georgiou et al., 2015; Comeau et al., 2019). 

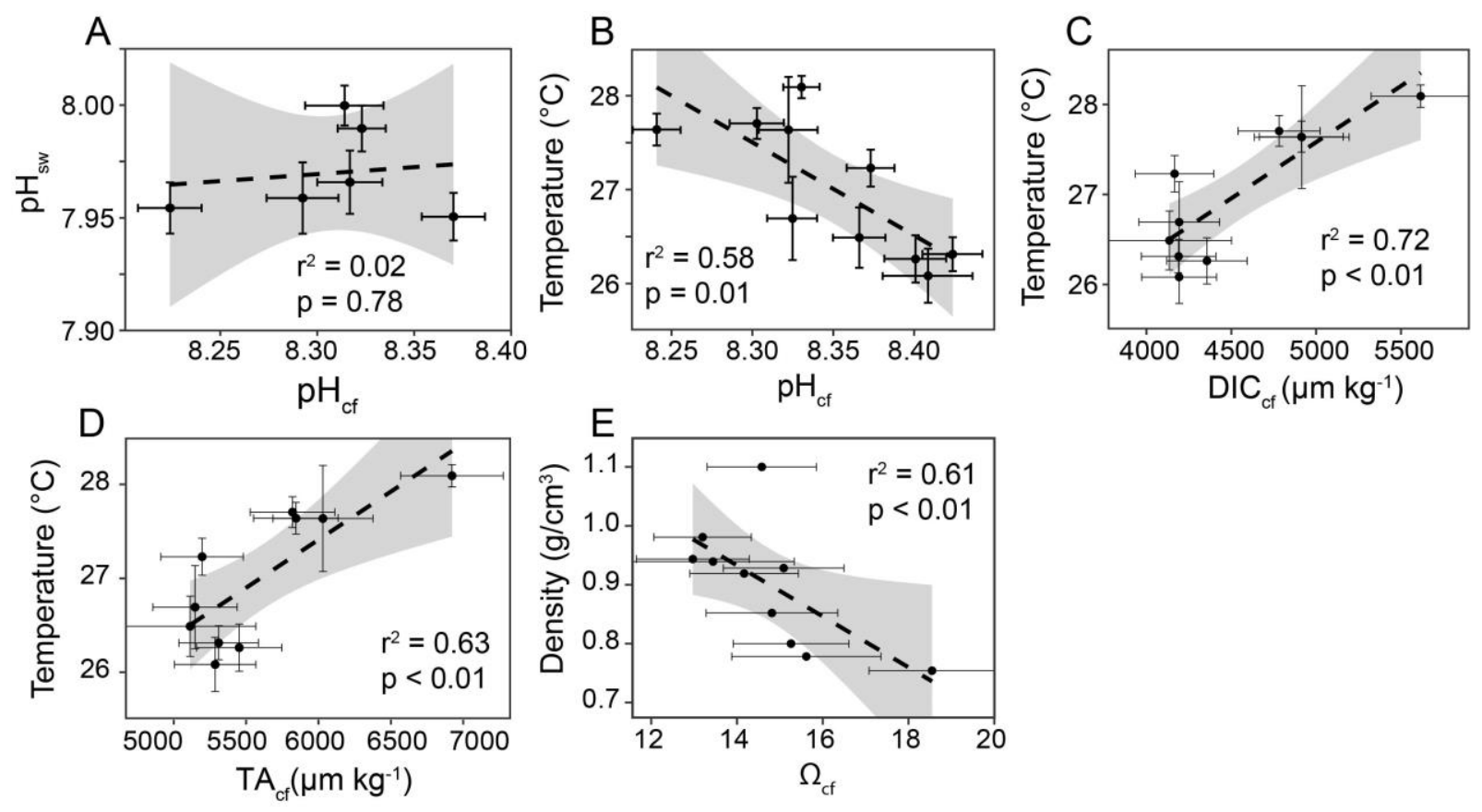

Figure 6: Controls on calcifying fluid carbonate chemistry parameters. Correlations between $\mathrm{pH}_{\mathrm{sw}}$ and $\mathrm{pH}_{\mathrm{cf}}$ (bulk $\delta^{11} \mathrm{~B}, \mathrm{a}$ ), as well as between seawater temperature and calcifying fluid carbonate chemistry parameters, such as $\mathrm{pH}_{\mathrm{cf}}(\mathrm{b}), \mathrm{DIC}_{\mathrm{cf}}(\mathrm{c})$ and $\mathrm{TA}_{\mathrm{cf}}(\mathrm{d})$ are shown. Furthermore, the correlation between $\Omega_{\mathrm{cf}}$ and skeletal density is presented (e).

417 Corals calcify predominantly during the day as light stimulates calcification (Buchsbaum \& Muscatine, 1971; Cohen et al., 2016). Potentially, highly resolved time series of $\delta^{11} \mathrm{~B}$ derived $\mathrm{pH}_{\mathrm{cf}}$ could thus be biased towards day time $\mathrm{pH}_{\mathrm{cf}}$ and consequently may record oscillations in day time $\mathrm{pH}_{\mathrm{cf}}$. However, no significant 15 days periodicity following the spring-neap tidal cycle as observed for day time $\mathrm{pH}_{\mathrm{sw}}$ and temperature has been found in time series of LA-MC-ICP-MS $\delta^{11} \mathrm{~B}$ derived $\mathrm{pH}_{\mathrm{cf}}$ (Fig. 5c and d, Fig. S9). This supports the numerical model results suggesting a limited diurnal variability in $\mathrm{pH}_{\mathrm{cf}}$ despite the substantial diurnal variabilities in $\mathrm{pH}_{\mathrm{sw}}$ (Fig. 4c) and temperature (Fig. 4b) observed on the reef flat. Furthermore, these findings are in accordance with previous studies that cultured corals under variable diurnal ranges in $\mathrm{pH}_{\mathrm{sw}}$ and found similar levels in $\mathrm{pH}_{\mathrm{cf}}$ upregulation across treatments (Cornwall et al., 2018), as well as no decline in calcification rates with increasing diurnal $\mathrm{pH}_{\mathrm{sw}}$ variability (Enochs et al., 2018). In our model simulations, the competing effects of varying $\mathrm{pH}_{\mathrm{sw}}$ and temperature on $\mathrm{pH}_{\mathrm{cf}}$ upregulation (e.g. Guo 2019) result in a nearly constant $\mathrm{pH}_{\mathrm{cf}}$ at the diurnal scale. However, as noted earlier, 
diurnal physiological processes, such as light dependent variations in zooxanthellae photosynthetic activity, are not considered in our model and may still induce some diurnal variability in $\mathrm{pH}_{\mathrm{cf}}$. Of note, a significant periodicity of 25-26 days in the de-trended time series of LA-MC-ICP-MS $\delta^{11} \mathrm{~B}$ derived $\mathrm{pH}_{\mathrm{cf}}$ (Fig. 5d) may relate to the accretion of dissepiments within the coral skeleton that follows the lunar cycle (DeCarlo \& Cohen, 2017).

Besides $\mathrm{pH}_{\mathrm{cf}}$, other calcifying fluid carbonate system parameters calculated from bulk derived $\delta^{11} \mathrm{~B}$ and $\mathrm{B} / \mathrm{Ca}$ also exhibit a seawater temperature dependency, such as $\mathrm{DIC}_{\mathrm{cf}}\left(\mathrm{r}^{2}=0.72, \mathrm{p}<\right.$ $0.01, \mathrm{n}=10$, Fig. $6 \mathrm{c})$ and $\mathrm{TA}_{\mathrm{cf}}\left(\mathrm{r}^{2}=0.63, \mathrm{p}<0.01, \mathrm{n}=10\right.$, Fig. 6d). Similarly, sub-annual variations in skeletal density suggest some positive relation with temperature, with lower density values in autumn and winter when seawater temperatures are low, and higher density in spring and summer under higher seawater temperatures (Fig. 3a and b), consistent with faster aragonite precipitation and thus skeletal densification at higher temperatures (Mollica et al., 2018; Guo et al., 2020). However, these sub-annual skeletal densities exhibited an apparent negative correlation with aragonite $\Omega_{\mathrm{cf}}\left(\mathrm{r}^{2}=0.44, \mathrm{p}=0.04, \mathrm{n}=5\right.$, Fig. 6e $)$, different from the positive correlation between inter-annual skeletal density and $\Omega_{\mathrm{cf}}$ observed in Porites collected from several Pacific reefs in Mollica et al. (2018). This difference likely reflects the interplay of multiple factors influencing coral skeletal density (e.g. extension rates, temperature, $\Omega_{\mathrm{cf}}$ ) on different time scales (Guo et al. 2020). Overall, our results support that coral calcification is affected by physiological modification of the calcifying fluid carbonate chemistry and that these modifications primarily follow variations in ambient seawater temperatures. However, while we have followed the DeCarlo et al. (2018) approach in converting $\mathrm{B} / \mathrm{Ca}$ to $\left[\mathrm{CO}_{3}^{2-}\right]$, it should also be noted that others have suggested there is a temperature dependency of boron incorporation into aragonite (Chen et al., 2015; Cai et al., 2016). This may be complicating the estimates of calcifying fluid carbonate system parameters we make here from $\mathrm{B} / \mathrm{Ca}$.

\section{Conclusions}

This study confirms that Porites $\mathrm{pH}_{\mathrm{cf}}$ is upregulated compared to ambient $\mathrm{pH}_{\mathrm{sw}}$ and that, on a season scale, seawater temperatures exert the primary control on $\mathrm{pH}_{\mathrm{cf}}$ upregulation rather than $\mathrm{pH}_{\mathrm{sw}}$ at our study location. Reduced reef flat $\mathrm{pH}_{\mathrm{sw}}$ resulted from dilution by meteoric water occurring in response to periodic rainfall events, and was not reflected in time series of $\mathrm{pH}_{\mathrm{cf}}$. The 
observed variations in $\mathrm{pH}_{\mathrm{cf}}$ upregulation that follow ambient seawater temperatures are likely related to the temperature dependency of calcification rates. The application of a recent numerical model of $\mathrm{pH}_{\mathrm{cf}}$ upregulation (Guo, 2019) and the novel usage of LA-MC-ICP-MS to determine skeletal $\delta^{11} \mathrm{~B}$ in high resolution (Standish et al., 2019) suggest that Porites also maintains $\mathrm{pH}_{\mathrm{cf}}$ upregulation under large diurnal variations in reef flat $\mathrm{pH}_{\mathrm{sw}}$ and temperature conditions, although, diurnally resolved measurements of $\mathrm{pH}_{\mathrm{cf}}$ are needed to validate this finding. The observed diurnal $\mathrm{pH}_{\mathrm{sw}}$ variability on Cecile Peninsula reef flat on Kiritimati Island was substantially higher than on the fore-reef, driven by ecological and tidal processes. In order to ensure calcification in such a dynamic $\mathrm{pH}_{\mathrm{sw}}$ environment, Porites likely maintains upregulation of calcifying fluid carbonate chemistry parameters at seasonal and diurnal time scales.

\section{Acknowledgments, Samples, and Data}

The authors would like to thank the Royal Society Te Apārangi Marsden Fund New Zealand for funding this project (Project no. UOA1513, to P.K.), as well as the Investment in Science Fund and The Andrew W. Mellon Foundation Endowed Fund for Innovative Research at the Woods Hole Oceanographic Institution (to W.G.). We would also like to acknowledge Heather GoringHarford, Megan Wilding, Bastian Hambach and J. Andy Milton from the University of Southampton, Emily Frost, Brendan Hall, Shane Cronin, Susan Owen and Catherine Hobbis from the University of Auckland, Taratau Kirata and Tataua from the Fishery Department of Kiritimati Island, Kim Currie and Judith Murdoch from the University of Otago, Andrew Lorrey and Christian Hyde from NIWA and the staff of the Mercy Radiology Auckland for their support during fieldwork, sample preparation and laboratory work.

Fieldwork was undertaken under Research Permit No. 010/16, provided by the Ministry of Environment, Lands and Agricultural Development, Government of Kiribati.

\section{Data Availability Statement}

The data used in this paper have been deposited in a general data repository. Data are available at https://auckland.figshare.com/articles/dataset/Knebel_2020_JGR_Oceans_12774632 (doi: 10.17608/k6.auckland.12774632).

\section{Conflict of Interest}


manuscript submitted to Journal of Geophysical Research: Oceans

488 The authors have no conflict of interest to declare. 


\section{References}

Al-Horani, F. A., Al-Moghrabi, S. M., \& de Beer, D. (2002). The mechanism of calcification and its relation to photosynthesis and respiration in the scleractinian coral Galaxea fascicularis. Marine Biology, 142(3), 419426. doi:10.1007/s00227-002-0981-8

Bakker, D. C. E., Pfeil, B., Landa, C. S., Metzl, N., O\&apos;Brien, K. M., Olsen, A., . . Xu, S. (2016). A multidecade record of high-quality fCO2 data in version 3 of the Surface Ocean CO2 Atlas (SOCAT). Earth System Science Data, 8(2), 383-413. doi:10.5194/essd-8-383-2016

Bates, N. R., Amat, A., \& Andersson, A. J. (2010). Feedbacks and responses of coral calcification on the Bermuda reef system to seasonal changes in biological processes and ocean acidification. Biogeosciences, 7(8), 25092530. doi:10.5194/bg-7-2509-2010

Bindoff, N. L., Cheung, W. W. L., Kairo, J. G., Arístegui, J., Guinder, V. A., Hallberg, R., . . Williamson, P. (2019). Changing Ocean, Marine Ecosystems, and Dependent Communities. In H. -. Pörtner, D. C. Roberts, V. Masson-Delmotte, P. Zhai, M. Tignor, E. Poloczanska, ... N. M. Weyer (Eds.), IPCC Special Report on the Ocean and Cryosphere in a Changing Climate In press.

Buchsbaum, V. P., \& Muscatine, L. (1971). Role of Symbiotic Algae (Zooxanthellae) in Coral Calcification. Biological Bulletin, 141(2), 350-363. doi:10.2307/1540123

Cai, W., Ma, Y., Hopkinson, B. M., Grottoli, A. G., Warner, M. E., Ding, Q., . . Wang, Y. (2016). Microelectrode characterization of coral daytime interior $\mathrm{pH}$ and carbonate chemistry. Nature Communications, 7(1), 11144. doi:10.1038/ncomms11144

Carricart-Ganivet, J. P., \& Barnes, D. J. (2007). Densitometry from digitized images of X-radiographs: Methodology for measurement of coral skeletal density. Journal of Experimental Marine Biology and Ecology, 344(1), 67-72. doi:10.1016/j.jembe.2006.12.018

Chalk, T. B., Standish, C. D., Angelo, C. D., Castillo, K. D., Milton, J. A., \& Foster, G. L. (2021). Mapping coral calcification strategies from in situ boron isotope and trace element measurements of the tropical coral Siderastrea siderea. Scientific Reports, 11(472) Retrieved from https://doi.org/10.1038/s41598-020-78778-1

Chan, W., \& Eggins, S. (2017). Calcification responses to diurnal variation in seawater carbonate chemistry by the coral Acropora formosa. Coral Reefs, 36(3), 763-772. doi:10.1007/s00338-017-1567-8 
Chen, T., Yu, K., Zhao, J., Yan, H., Song, Y., Feng, Y., \& Chen, T. (2015). Testing coral paleothermometers (B/Ca, $\mathrm{Mg} / \mathrm{Ca}, \mathrm{Sr} / \mathrm{Ca}, \mathrm{U} / \mathrm{Ca}$ and $\delta \mathrm{18O})$ under impacts of large riverine runoff. Acta Oceanologica Sinica, 34(8), 2026. doi:10.1007/s13131-015-0705-9

Cobb, K. M., Cheng, H., Edwards, R. L., \& Charles, C. D. (2003). El Niño/Southern Oscillation and tropical Pacific climate during the last millennium. Nature, 424(6946), 271-276. doi:10.1038/nature01779

Cohen, I., Dubinsky, Z., \& Erez, J. (2016). Light Enhanced Calcification in Hermatypic Corals: New Insights from Light Spectral Responses. Frontiers in Marine Science, 2 doi:10.3389/fmars.2015.00122

Comeau, S., Cornwall, C. E., \& McCulloch, M. T. (2017). Decoupling between the response of coral calcifying fluid pH and calcification to ocean acidification. Scientific Reports (Nature Publisher Group), 7(1), 7573. doi:10.1038/s41598-017-08003-Z

Comeau, S., Cornwall, C. E., DeCarlo, T. M., Doo, S. S., Carpenter, R. C., \& McCulloch, M. T. (2019). Resistance to ocean acidification in coral reef taxa is not gained by acclimatization. Nature Climate Change, 9(6), $477-$ 483. doi:10.1038/s41558-019-0486-9

Comeau, S., Cornwall, C. E., DeCarlo, T. M., Krieger, E., \& McCulloch, M. T. (2018). Similar controls on calcification under ocean acidification across unrelated coral reef taxa. Global Change Biology, 24(10), 48574868. doi:10.1111/gcb.14379

Constantz, B. R. (1986). Coral Skeleton Construction: A Physiochemically Dominated Process. Palaios, 1(2), 152157. doi: $10.2307 / 3514508$

Cornwall, C. E., Comeau, S., DeCarlo, T. M., Moore, B., D'Alexis, Q., \& McCulloch, M. T. (2018). Resistance of corals and coralline algae to ocean acidification: physiological control of calcification under natural $\mathrm{pH}$ variability. Proceedings. Biological Sciences, 285(1884), 20181168. doi:10.1098/rspb.2018.1168

Cyronak, T., Andersson, A. J., Langdon, C., Albright, R., Bates, N. R., Caldeira, K., .. . Yamamoto, S. (2018). Taking the metabolic pulse of the world's coral reefs. PloS One, 13(1), e0190872. doi:10.1371/journal.pone.0190872

Cyronak, T., Schulz, K. G., \& Jokiel, P. L. (2016). The Omega myth: what really drives lower calcification rates in an acidifying ocean. ICES Journal of Marine Science, 73(3), 558-562. doi:10.1093/icesjms/fsv075 
Cyronak, T., Takeshita, Y., Courtney, T. A., DeCarlo, E. H., Eyre, B. D., Kline, D. I., . . Andersson, A. J. (2019). Diel temperature and $\mathrm{pH}$ variability scale with depth across diverse coral reef habitats. Limnology and Oceanography Letters, 5(2) doi:10.1002/lol2.10129

DeCarlo, T. M., Cohen, A. L., Wong, G. T. F., Shiah, F., Lentz, S. J., Davis, K. A., . . Lohmann, P. (2017). Community production modulates coral reef $\mathrm{pH}$ and the sensitivity of ecosystem calcification to ocean acidification. Journal of Geophysical Research: Oceans, 122(1), 745-761. doi:10.1002/2016JC012326

DeCarlo, T. M., Holcomb, M., \& McCulloch, M. T. (2018). Reviews and syntheses: revisiting the boron systematics of aragonite and their application to coral calcification. Biogeosciences, 15, 2819-2834. doi:10.5194/bg-152819-2018

DeCarlo, T., \& Cohen, A. (2017). Dissepiments, density bands and signatures of thermal stress in Porites skeletons. Coral Reefs, 36(3), 749-761. doi:10.1007/s00338-017-1566-9

DeCarlo, T., Ross, C., \& McCulloch, M. (2019). Diurnal cycles of coral calcifying fluid aragonite saturation state. Marine Biology, 166(3), 1-6. doi:10.1007/s00227-019-3468-6

Dickson, A. G., Sabine, C. L., \& Christian, J. R. (2007). Guide to Best Practices for Ocean CO2 Measurement. ( No. 3).PICES Special Publication.

D'Olivo, J. P., Ellwood, G., DeCarlo, T. M., \& McCulloch, M. T. (2019). Deconvolving the long-term impacts of ocean acidification and warming on coral biomineralisation. Earth and Planetary Science Letters, 526, 115785. doi:10.1016/j.eps1.2019.115785

Doney, S. C., Busch, D. S., Cooley, S. R., \& Kroeker, K. J. (2020). The Impacts of Ocean Acidification on Marine Ecosystems and Reliant Human Communities. Annual Review of Environment and Resources, 45(1), 83-112. doi:10.1146/annurev-environ-012320-083019

Duarte, C. M., Hendriks, I. E., Moore, T. S., Olsen, Y. S., Steckbauer, A., Ramajo, L., . . McCulloch, M. (2013). Is Ocean Acidification an Open-Ocean Syndrome? Understanding Anthropogenic Impacts on Seawater pH. Estuaries and Coasts, 36, 221-236. doi:10.1007/s12237-013-9594-3

Enochs, I. C., Manzello, D. P., Jones, P. J., Aguilar, C., Cohen, K., Valentino, L., . . Lirman, D. (2018). The influence of diel carbonate chemistry fluctuations on the calcification rate of Acropora cervicornis under present day and future acidification conditions. Journal of Experimental Marine Biology and Ecology, 506, 135-143. doi:10.1016/j.jembe.2018.06.007 
manuscript submitted to Journal of Geophysical Research: Oceans

Foster, G. (2008). Seawater pH, pCO2 and CO2-3] variations in the Caribbean Sea over the last 130 kyr: A boron isotope and B/Ca study of planktic foraminifera. Earth and Planetary Science Letters, 271, 254-266. doi:10.1016/j.eps1.2008.04.015

Foster, G. L., Hönisch, B., Paris, G., Dwyer, G. S., Rae, J. W. B., Elliott, T., . . Vengosh, A. (2013). Interlaboratory comparison of boron isotope analyses of boric acid, seawater and marine $\mathrm{CaCO} 3$ by MC-ICPMS and NTIMS. Chemical Geology, 358, 1-14. doi:10.1016/j.chemgeo.2013.08.027

Foster, G. L., \& Rae, J. W. B. (2016). Reconstructing Ocean pH with Boron Isotopes in Foraminifera. Annual Review of Earth and Planetary Sciences, 44(1), 207-237. doi:10.1146/annurev-earth-060115-012226

Fowell, S. E., Foster, G. L., Ries, J. B., Castillo, K. D., Vega, E., Tyrrell, T., . . Chalk, T. B. (2018). Historical Trends in pH and Carbonate Biogeochemistry on the Belize Mesoamerican Barrier Reef System. Geophysical Research Letters, 45(7), 3228-3237. doi:10.1002/2017GL076496

Fowell, S. E., Sandford, K., Stewart, J. A., Castillo, K. D., Ries, J. B., \& Foster, G. L. (2016). Intrareef variations in $\mathrm{Li} / \mathrm{Mg}$ and $\mathrm{Sr} / \mathrm{Ca}$ sea surface temperature proxies in the Caribbean reef-building coral Siderastrea siderea. Paleoceanography, 31(10), 1315-1329. doi:10.1002/2016PA002968

Friedlingstein, P., Jones, M. W., O'Sullivan, M., Anew, R. M., Hauck, J., Peters, G. P., . . Zaehle, S. (2019). Global carbon budget 2019. Earth System Science Data, 11(4), 1783. Retrieved from https://www.narcis.nl/publication/RecordID/oai:dspace.library.uu.nl:1874\%2F388384

Gattuso, J. -., Pichon, M., Delesalle., B., \& Frankignoulle, M. (1993). Community metabolism and air-sea CO2 fluxes in a coral reef ecosystem (Moorea, French Polynesia). Marine Ecology Progress Series, 96(3), 259-267. doi:10.3354/meps096259

Gattuso, J. P., Epitalon, J., Lavigne, H., \& Orr, J. (2019). seacarb: Seawater Carbonate Chemistry. R package

Gattuso, J., Allemand, D., \& Frankignoulle, M. (1999). Photosynthesis and Calcification at Cellular, Organismal and Community Levels in Coral Reefs: A Review on Interactions and Control by Carbonate Chemistry. American Zoologist, 39(1), 160-183. doi:10.1093/icb/39.1.160

Georgiou, L., Falter, J., Trotter, J., Kline, D. I., Holcomb, M., Dove, S. G., . . McCulloch, M. (2015). pH homeostasis during coral calcification in a free ocean CO2enrichment (FOCE) experiment, Heron Island reef flat, Great Barrier Reef. Proceedings of the National Academy of Sciences, 112(43), 13219-13224. doi:10.1073/pnas.1505586112 
manuscript submitted to Journal of Geophysical Research: Oceans

598

599

600

601

602

603

604

605

606

607

608

609

610

611

612

613

614

615

616

617

618

619

620

621

622

623

Guo, W. (2019). Seawater temperature and buffering capacity modulate coral calcifying pH. Scientific Reports, 9(1), 1-13. doi:10.1038/s41598-018-36817-y

Guo, W., Bokade, R., Cohen, A. L., Mollica, N. R., Leung, M., \& Brainard, R. E. (2020). Ocean Acidification has Impacted Coral Growth on the Great Barrier Reef. Geophysical Research Letters, 47(19) doi:10.1029/2019GL086761

Gutjahr, M., Bordier, L., Douville, E., Farmer, J., Foster, G. L., Hathorne, E. C., . . You, C. (2020). Sub-permil interlaboratory consistency for solution-based boron isotope analyses on marine carbonates. Geostand Geoanal Res., Retrieved from http://hdl.handle.net/10023/20982

Hammer, Ø, Harper, D. A. T., \& Ryan, P. D. (2001). PAST: Paleontological statistics software package for education and data analysis. Palaeontologia Electronica 4(1): 9pp:

Henehan, M. J., Foster, G. L., Rae, J. W. B., Prentice, K. C., Erez, J., Bostock, H. C., . . Wilson, P. A. (2015). Evaluating the utility of $\mathrm{B} / \mathrm{Ca}$ ratios in planktic foraminifera as a proxy for the carbonate system: A case study of Globigerinoides ruber. Geochemistry, Geophysics, Geosystems, 16(4), 1052-1069. doi:10.1002/2014GC005514

Hönisch, B., Hemming, N. G., Grottoli, A. G., Amat, A., Hanson, G. N., \& Bijma, J. (2004). Assessing scleractinian corals as recorders for paleo-pH: Empirical calibration and vital effects. Geochimica Et Cosmochimica Acta, 68(18), 3675-3685. doi:10.1016/j.gca.2004.03.002

Kench, P. S., McLean, R. F., Owen, S. D., Ryan, E., Morgan, K. M., Ke, L., . . Roy, K. (2019). Climate-forced sealevel lowstands in the Indian Ocean during the last two millennia. Nature Geosecience, doi:10.1038/s41561019-0503-7

Klochko, K., Kaufman, A. J., Yao, W., Byrne, R. H., \& Tossell, J. A. (2006). Experimental measurement of boron isotope fractionation in seawater. Earth and Planetary Science Letters, 248(1), 276-285. doi:10.1016/j.epsl.2006.05.034

Krief, S., Hendy, E. J., Fine, M., Yam, R., Meibom, A., Foster, G. L., \& Shemesh, A. (2010). Physiological and isotopic responses of scleractinian corals to ocean acidification. Geochimica Et Cosmochimica Acta, 74(17), 4988-5001. doi:10.1016/j.gca.2010.05.023 
Kubota, K., Yokoyama, Y., Ishikawa, T., Suzuki, A., \& Ishii, M. (2017). Rapid decline in pH of coral calcification fluid due to incorporation of anthropogenic CO2. Scientific Reports (Nature Publisher Group), 7, 1. doi:10.1038/s41598-017-07680-0

Lamberts, A. E. (1978). Coral growth: alizarin method. In D. R. Stoddart, \& R. E. Johannes (Eds.), Coral reefs: research methods (pp. 523-527). Paris: Unesco.

Lantz, C., Lantz, C., Atkinson, M., Atkinson, M., Winn, C., Winn, C., . . Kahng, S. (2014). Dissolved inorganic carbon and total alkalinity of a Hawaiian fringing reef: chemical techniques for monitoring the effects of ocean acidification on coral reefs. Coral Reefs, 33(1), 105-115. doi:10.1007/s00338-013-1082-5

Martz, T. R., Connery, J. G., \& Johnson, K. S. (2010). Testing the Honeywell Durafet@ for seawater pH applications. Limnology and Oceanography: Methods, 8(5), 172-184. doi:10.4319/lom.2010.8.172

McCulloch, M. T., D'Olivo, J. P., Falter, J., Georgiou, L., Holcomb, M., Montagna, P., \& Trotter, J. A. (2018). Boron Isotopic Systematics in Scleractinian Corals and the Role of pH Up-regulation. In H. Marshall, \& G. L. Foster (Eds.), Boron Isotopes The Fifth Element (pp. 145-162). Switzerland: Springer International Publishing AG.

McCulloch, M. T., D'olivo, J. P., Falter, J., Holcomb, M., \& Trotter, J. A. (2017). Coral calcification in a changing World and the interactive dynamics of pH and DIC upregulation. Nature Communications, 8, 15686. doi:10.1038/ncomms 15686

McCulloch, M., Falter, J., Trotter, J., \& Montagna, P. (2012). Coral resilience to ocean acidification and global warming through pH up-regulation. Nature Climate Change, 2(8), 623. doi:10.1038/nclimate1473

Miller, C. A., Pocock, K., Evans, W., \& Kelley, A. L. (2018). An evaluation of the performance of Sea-Bird Scientific's SeaFET TM autonomous pH sensor: considerations for the broader oceanographic community. Ocean Science, 14(4), 751-768. doi:10.5194/os-14-751-2018

Mollica, N. R., Guo, W., Cohen, A. L., Huang, K., Foster, G. L., Donald, H. K., \& Solow, A. R. (2018). Ocean acidification affects coral growth by reducing skeletal density. Proceedings of the National Academy of Sciences of the United States of America, 115(8), 1754-1759. doi:10.1073/pnas.1712806115

Morrison, R. J., \& Woodroffe, C. D. (2009). The Soils of Kiritimati (Christmas) Island, Kiribati, Central Pacific: New Information and Comparison with Previous Studies1. Pacific Science, 63(3), 397-411. doi:10.2984/049.063.0308 
Okai, T., Suzuki, A., Kawahata, H., Terashima, S., \& Imai, N. (2002). Preparation of a New Geological Survey of Japan Geochemical Reference Material: Coral JCp-1. Geostandards Newsletter, 26(1), 95-99. doi:10.1111/j.1751-908X.2002.tb00627.x

R Core Team. (2019). A language and environment for statistical computing. Vienna, Austria (URL: https://www.R-project.org/):

Rae, J. W. B., Foster, G. L., Schmidt, D. N., \& Elliott, T. (2011). Boron isotopes and B/Ca in benthic foraminifera: Proxies for the deep ocean carbonate system. Earth and Planetary Science Letters, 302(3), 403-413. doi:10.1016/j.eps1.2010.12.034

Rhein, M., Rintoul, S. R., Aoki, S., Campos, E., Chambers, D., Feely, R. A., . . Wang, F. (2013). Observations: Ocean. In T. F. Stocker, D. Qin, G. -. Plattner, M. Tignor, S. K. Allen, J. Boschung, . . P. M. Midgley (Eds.), Climate Change 2013: The Physical Science Basis. Contribution of Working Group 1 to the Fifth Assessment Report of the Intergovernmental Panel on Climate Change. Cambridge, United Kingdom and New York, NY, USA: Cambridge University press.

Ross, C. L., Falter, J. L., \& McCulloch, M. T. (2017). Active modulation of the calcifying fluid carbonate chemistry $(\delta 11 \mathrm{~B}, \mathrm{~B} / \mathrm{Ca})$ and seasonally invariant coral calcification at sub-tropical limits. Scientific Reports, 7(1), 1-11. doi:10.1038/s41598-017-14066-9

Sadekov, A., Lloyd, N. S., Misra, S., Trotter, J., D'Olivo, J., \& McCulloch, M. (2019). Accurate and precise microscale measurements of boron isotope ratios in calcium carbonates using laser ablation multicollectorICPMS. Journal of Analytical Atomic Spectrometry, 34(3), 550-560. doi:10.1039/C8JA00444G

Scoffin, T. P., Stoddart, D. R., \& Rosen, B. R. (1978). The Nature and Significance of Microatolls. Philosophical Transactions of the Royal Society of London. B, Biological Sciences, 284(999), 99-122. doi:10.1098/rstb.1978.0055

Sevilgen, D. S., Venn, A. A., Hu, M. Y., Tambutté, E., de Beer, D., Planas-Bielsa, V., \& Tambutté, S. (2019). Full in vivo characterization of carbonate chemistry at the site of calcification in corals. Science Advances, 5(1), eaau7447. doi:10.1126/sciadv.aau7447

Shaw, E. C., McNeil, B. I., \& Tilbrook, B. (2012). Impacts of ocean acidification in naturally variable coral reef flat ecosystems. Journal of Geophysical Research: Oceans, 117(C3), n/a. doi:10.1029/2011JC007655 
Smith, S. V. (1973). Carbon Dioxide Dynamics: A Record of Organic Carbon Production, Respiration, and Calcification in the Eniwetok Reef Flat Community. Limnology and Oceanography, 18(1), 106-120.

Standish, C. D., Chalk, T. B., Babila, T. L., Milton, J. A., Palmer, M. R., \& Foster, G. L. (2019). The effect of matrix interferences on in situ boron isotope analysis by laser ablation MC-ICP-MS. Rapid Commun Mass Spectrom, 33(10), 959- 968. doi:10.1002/rcm.8432

Thil, F., Blamart, D., Assailly, C., Lazareth, C. E., Leblanc, T., Butsher, J., \& Douville, E. (2016). Development of laser ablation multi-collector inductively coupled plasma mass spectrometry for boron isotopic measurement in marine biocarbonates: new improvements and application to a modernPoritescoral. Rapid Communications in Mass Spectrometry, 30(3), 359-371. doi:10.1002/rcm.7448

Venn, A., Tambutté, E., Holcomb, M., Allemand, D., \& Tambutté, S. (2011). Live Tissue Imaging Shows Reef Corals Elevate $\mathrm{pH}$ under Their Calcifying Tissue Relative to Seawater. PloS One, 6(5), e20013. doi:10.1371/journal.pone.0020013

Wall, M., Fietzke, J., Schmidt, G. M., Fink, A., Hofmann, L. C., de Beer, D., \& Fabricius, K. E. (2016). Internal pH regulation facilitates in situ long-term acclimation of massive corals to end-of-century carbon dioxide conditions. Scientific Reports, 6, 30688. doi:10.1038/srep30688

Walsh, S. M. (2011). Ecosystem-Scale Effects of Nutrients and Fishing on Coral Reefs. Journal of Marine Biology, 2011, 1-13. doi:10.1155/2011/187248

Woodroffe, C. D., McGregor, H. V., Lambeck, K., Smithers, S. G., \& Fink, D. (2012). Mid-Pacific microatolls record sea-level stability over the past 5000 yr. Geology, 40(10), 951. doi:10.1130/G33344.1

Woodroffe, C. D., Beech, M. R., \& Gagan, M. K. (2003). Mid-late Holocene El Niño variability in the equatorial Pacific from coral microatolls. Geophysical Research Letters, 30(7), 1358-n/a. doi:10.1029/2002GL015868

Zhang, C., Huang, H., Ye, C., Huang, L., Li, X., Lian, J., \& Liu, S. (2013). Diurnal and seasonal variations of carbonate system parameters on Luhuitou fringing reef, Sanya Bay, Hainan Island, South China Sea. Deep-Sea Research. Part II, Topical Studies in Oceanography, 96, 65-74. doi:10.1016/j.dsr2.2013.02.013 